\title{
NORMY OSTROŻNOŚCIOWE OCENY RYZYKA KREDYTOBIORCY HIPOTECZNEGO
}

\section{WPROWADZENIE}

Prawidłowe zarządzanie ryzykiem kredytowym jest konieczne do zapewnienia stabilności europejskiego systemu finansowego, w którym sektor bankowy ma dominująca pozycję. Ostatni kryzys finansowy udowodnił, że błędna ocena takiego ryzyka może wiązać się z tzw. efektem zarażania ${ }^{1}$ oraz sprzężeniami ze sferą realna. Sekurytyzacja zobowiązań klientów sub-prime, prowadząca do nadmiernej podaży papierów wartościowych oraz kredytowych instrumentów pochodnych, jest uznawana za kluczowe źródło powstania bańki spekulacyjnej w USA². Po jej pęknięciu negatywne skutki przeniosły się na europejski system bankowy, który wcześniej zakupił amerykańskie instrumenty finansowe.

Reakcją na spadek dochodowość europejskich banków było silne ograniczenie finansowania gospodarki realnej. Sektorem, który w pierwszej kolejności odczuł skutki tzw. załamania kredytowego (credit crunch) ${ }^{3}$, stało się budownictwo. W efekcie (jak np. w Hiszpanii lub Irlandii ${ }^{4}$ ) istotnie potaniały nieruchomości, zmniejszyły się inwestycje budowalne, a także zatrudnienie w tym sektorze.

Po kryzysie finansowym ustanowiono Europejski System Nadzoru Finansowego (ESNF) ${ }^{5}$, który formalnie swymi kompetencjami obejmuje Unię Europejską. Jednakże tzw. jednolity paszport pozwalający na otwieranie zagranicznych oddziałów banków bez konieczności uzyskiwania kolejnego zezwolenia ${ }^{6}$ w praktyce rozszerzył mandat ESNF na państwa należące do Europejskiego Obszaru Gospodarczego (EOG) ${ }^{7}$. Zupełnie nowym elementem działania ESNF jest nadzór makroostrożnościowy ${ }^{8}$. Jednym z obszarów najszerzej poddanych

${ }^{1}$ Wyciślak (2012): 244-245 i cytowana tam literatura.

${ }^{2}$ Nieborak (2010): 100-101.

${ }^{3}$ Rosati (2016): 461, 475-476; Hainz, Hristov (2017): 66-69.

${ }^{4}$ Norris, Byrne (20015): 6-12.

${ }^{5}$ Szpringer, Szpringer (2017): 85 i przytaczana tam literatura.

${ }^{6}$ Grosmann, Leblond (2011): 423.

${ }^{7}$ EOG obejmuje Unię Europejska, Islandię, Liechtenstein oraz Norwegię. Ostatnie trzy państwa aktywnie uczestniczą w pracach gremiów decyzyjnych ESNF.

${ }_{8}$ Ten rodzaj nadzoru ma obejmować swym zasięgiem cały rynek finansowy. Jednakże w pierwszym okresie funkcjonowania europejskich regulacji makroostrożnościowych zdecydowany nacisk położono na instrumenty oddziałujące na sektor bankowy. Z tego względu na 
oddziaływaniu instrumentów uważanych za narzędzia tego nadzoru okazało się kredytowanie rynku nieruchomości.

Środki nadzorcze, które mogą wpływać na kredytowanie hipoteczne, można rozmaicie kategoryzować. Z formalnego punktu widzenia należy wyróżnić instrumenty zharmonizowane prawem unijnym ${ }^{9}$ oraz takie, których stosowanie przewidują tylko regulacje wybranego członka EOG. Wykorzystując założenia ekonomiczne, można mówić o środkach oddziałujących na kredytodawców (pozacenowe czynniki kształtujące podaż kredytów) bądź kredytobiorców (co oznacza wpływ na popyt na kredyty).

Warto odnotować, że instrumenty zharmonizowane regułami obowiązującymi w EOG rzutują tylko na kredytodawców. Dlatego celem niniejszego artykułu jest przedstawienie środków skoncentrowanych na zadłużających się. Tezą przyświecającą autorom było stwierdzenie, że mimo obserwowanego po kryzysie finansowym dążenia do ujednolicenia w UE przepisów związanych z rynkiem finansowym środki makroostrożnościowe wykazują zróżnicowanie. Wskazuje to na możliwość ich dostosowania do priorytetów twórców polityk publicznych w danym kraju.

\section{KLASYFIKACJA NIEZHARMONIZOWANYCH ŚRODKÓW NADZORCZYCH WPLYWAJĄCYCH NA KREDYTOBIORCÓW HIPOTECZNYCH}

Częściowo korzystając z systematyki stosowanej przez Europejska Radę ds. Ryzyka Systemowego ${ }^{10}$, niezharmonizowane środki oddziałujace na kredytobiorców hipotecznych podzielić można na:

potrzeby niniejszego artykułu można przyjąć, że nadzór makroostrożnościowy jest nadzorem bankowym sensu largo. Szerzej o nadzorze makroostrożnościowym piszą: Olszak (2012): 7-32; Freixas, Laeven, Peydró (2015).

${ }^{9} \mathrm{~W}$ tym przypadku podstawowymi aktami są: rozporządzenie Parlamentu Europejskiego i Rady (UE) nr 575/2013 z 26 czerwca 2013 r. w sprawie wymogów ostrożnościowych dla instytucji kredytowych i firm inwestycyjnych (Dz. Urz. UE L 176/1 z 27.06.2013 r.) oraz dyrektywa Parlamentu Europejskiego i Rady 2013/36/UE z 26 czerwca 2013 r. w sprawie warunków dopuszczenia instytucji kredytowych do działalności oraz nadzoru ostrożnościowego nad instytucjami kredytowymi i firmami inwestycyjnymi (Dz. Urz. UE L 176/338 z 27.06.2013 r.).

${ }^{10}$ ESRB (2018). Wspomniana Rada jest organem nadzoru makroostrożnościowego Unii Europejskiej. W jej pracach uczestniczą także przedstawiciele Islandii, Liechtensteinu oraz Norwegii. Autorzy uważaja, że nie można a priori przyjać, że zjawiska kryzysowe zachodzące w jednym z państw objętych wspólnym rynkiem finansowym nie moga negatywnie oddziaływać na inne, tylko z uwagi na dysparytet potencjałów gospodarczych. Przykładem jest Islandia, w której załamanie sektora bankowego w 2008 r. bardzo silnie uderzyło w system gwarantowania depozytów Wielkiej Brytanii i Holandii - zob. Legutko (2017): 125. Z kolei błędna deregulacja norweskiego sektora bankowego z końca lat osiemdziesiątych XX w., która powtórzono w Szwecji oraz Finlandii, pozwoliła na zrozumienie potrzeby uzupełnienia nadzoru mikroostrożnościowego o komponenty mitygujące ryzyko systemowe oraz ustanowienia zasad międzynarodowego zarządzania kryzysowego - zob. Jonung (2008): 587-589. Dlatego w dalszej części pracy analizowane będa instrumenty stosowane we wszystkich państwach członkowskich EOG. 
1) ograniczające wykorzystanie wartości nieruchomości jako zabezpieczenia kredytu (ang. collateral stretch instruments),

2) ustanawiające wymogi dochodowe dla kredytobiorcy (ang. income stretch instruments).

Najszerzej wykorzystywanym instrumentem należącym do pierwszej kategorii sa wymogi loan-to-value (LTV), tj. stosunek wartości nieruchomości stanowiącej zabezpieczenie kredytu do wartości finansowania udzielonego przez bank. Podstawowymi środkami z drugiej kategorii sa wymogi DSTI (ang. debt service to income) ograniczające udział wydatków na obsługę kredytu w miesięcznym dochodzie kredytobiorcy, oraz wymogi DTI (ang. debt to income) limitujące wartość całkowitego zadłużenia do wybranej krotności dochodu kredytobiorcy ${ }^{11}$. Powyższe środki mają swoje odpowiedniki dla bankowego finansowania nieruchomości komercyjnych, choć ich praktyczne wdrożenie jest zdecydowanie rzadsze niż oddziaływanie na gospodarstwa domowe.

\section{ZAKRES STOSOWANIA ŚRODKÓW ODDZIALUJĄCYCH NA KREDYTOBIORCÓW HIPOTECZNYCH}

Środki nadzorcze ograniczające popyt na kredyty hipoteczne wprowadziły 23 z 31 państw tworzących Europejski Obszar Gospodarczy. Spośród nich 22 państwa zastosowały limit LTV dla kredytowania nieruchomości mieszkaniowej, a tylko dwa sięgnęły do analogicznego instrumentu powiązanego z nieruchomościami komercyjnymi. Siedemnaście jurysdykcji zdecydowało się ustanowić wymogi dochodowe dla gospodarstw domowych i tylko jeden kraj ustanowił analogiczne bariery dla nabywców nieruchomości komercyjnych.

Analizowane instrumenty moga zostać wprowadzone jako normy bezwzględnie wiążące wszystkich bądź wybranych uczestników rynku. Wspomniane środki mogą również przyjąć postać rekomendacji organów nadzoru finansowego i stać się elementem tzw. soft law ${ }^{12}$, które nie stanowiąc formalnie źródła prawa, i tak kształtują zachowania rynkowe ${ }^{13}$.W tabeli 1 przedstawiono podstawowe informacje o charakterze prawnym środków nadzorczych ograniczajacych popyt na kredyty zabezpieczone hipotecznie.

Zatem należy stwierdzić, że Cypr, Litwa i Polska są najbardziej restrykcyjnymi członkami EOG, gdyż w każdym z wymienionych państw wprowadzono środki należące aż do trzech wyróżnionych grup. Warto zauważyć, że spośród 5 największych (pod względem populacji) państw EOG tylko Wielka Brytania wprowadziła środki będące tu przedmiotem analizy ${ }^{14}$. Szczególne zdziwienie

11 Formalne ujęcie powyższych wskaźników zawiera Zalecenie Europejskiej Rady ds. Ryzyka Systemowego z 31 października 2016 r. w sprawie uzupełniania luk w danych dotyczących sektora nieruchomości (Dz. Urz. UE C 31/1 z 31.01.2017 r. - dalej jako: zalecenie ERRS/2016/14).

12 Przykładowo Nieborak (2017) i cytowana tam literatura bądź Brummer (2015): 218-245.

13 Szerzej na ten temat w kontekście prawa unijnego pisze Fedorowicz (2013): 151-157.

14 Niemiecki organ nadzoru (BaFin) uzyskał w 2017 r. uprawnienia do ustanawiania limitu LTV, ale dotąd nie skorzystał z tego środka - zob. BaFin, Residential mortgage loans: BaFin 
powinno jednać budzić odstapienie od korzystania z powyższych rozwiązań przez Hiszpanię, która bardzo istotnie odczuła skutki globalnego kryzysu finansowego. Z kolei wspomniane działania makroostrożnościowe Portugalia wprowadziła dopiero w połowie 2018 r. $^{15}$

\section{Tabela 1}

Zakres stosowania i sposób wprowadzenia instrumentów oddziałujących na kredytobiorców hipotecznych w państwach EOG (stan z czerwca 2019 r.)

\begin{tabular}{|c|c|c|c|c|c|c|c|c|}
\hline \multirow{3}{*}{ Państwo } & \multicolumn{4}{|c|}{$\begin{array}{c}\text { Ograniczenia } \\
\text { dotyczące zabezpieczenia }\end{array}$} & \multicolumn{4}{|c|}{$\begin{array}{c}\text { Wymogi } \\
\text { dotyczące dochodu }\end{array}$} \\
\hline & \multicolumn{2}{|c|}{$\begin{array}{l}\text { nieruchomości } \\
\text { mieszkaniowe }\end{array}$} & \multicolumn{2}{|c|}{$\begin{array}{c}\text { nieruchomości } \\
\text { komercyjne }\end{array}$} & \multicolumn{2}{|c|}{$\begin{array}{c}\text { nieruchomości } \\
\text { mieszkaniowe }\end{array}$} & \multicolumn{2}{|c|}{$\begin{array}{c}\text { nieruchomości } \\
\text { komercyjne }\end{array}$} \\
\hline & prawo & $\mathbf{R N}^{a}$ & prawo & RN & prawo & RN & prawo & RN \\
\hline Austria & $\sqrt{b}$ & $-^{c}$ & - & - & - & $\checkmark$ & - & - \\
\hline Cypr & $\checkmark$ & - & $\checkmark$ & - & $\checkmark$ & - & - & - \\
\hline Czechy & - & $\checkmark$ & - & - & - & $\checkmark$ & - & - \\
\hline Dania & - & $\checkmark$ & - & - & - & $\checkmark$ & - & - \\
\hline Estonia & $\checkmark$ & - & - & - & $\checkmark$ & - & - & - \\
\hline Finlandia & $\checkmark$ & - & - & - & - & - & - & - \\
\hline Holandia & $\checkmark$ & - & - & - & $\checkmark$ & - & - & - \\
\hline Islandia & $\checkmark$ & - & - & - & - & - & - & - \\
\hline Irlandia & $\checkmark$ & - & - & - & - & $\checkmark$ & - & - \\
\hline Lichtenstein & $\checkmark$ & - & - & - & - & - & - & - \\
\hline Litwa & $\checkmark$ & - & - & - & $\checkmark$ & - & $\checkmark$ & - \\
\hline Luksemburg & $\checkmark$ & - & - & - & - & - & - & - \\
\hline Łotwa & $\checkmark$ & - & - & - & - & - & - & - \\
\hline Malta & $\checkmark$ & - & - & - & - & - & - & - \\
\hline Norwegia & $\checkmark$ & - & - & - & $\checkmark$ & - & - & - \\
\hline Polska & - & $\checkmark$ & - & $\checkmark$ & - & $\checkmark$ & - & - \\
\hline Portugalia & - & $\checkmark$ & - & - & - & $\checkmark$ & - & - \\
\hline Rumunia & $\checkmark$ & - & - & - & $\checkmark$ & - & - & - \\
\hline Słowacja & $\checkmark$ & - & - & - & $\checkmark$ & - & - & - \\
\hline
\end{tabular}

gains new macro-prudential powers, <https://www.bafin.de/SharedDocs/Veroeffentlichungen/EN/ Fachartikel/2017/fa_bj_1706_wohnimmobilienkredite_en.html> [dostęp: 15.03.2019]. Z kolei we Francji uważa się, że podobne instrumenty nie są potrzebne, gdyż dobrze działa samoregulacja rynkowa ustanawiająca wewnętrzne limity, a ponadto hipoteczne zabezpieczanie kredytów ma drugorzędne znaczenie w sytuacji powszechnego korzystania z gwarancji udzielanych kredytobiorcom przez wyspecjalizowane podmioty - zob. Dietsch, Welter-Nicol (2014): 8-9.

${ }_{15} \mathrm{BdP}$, Banco de Portugal applies macroprudential measures to new credit agreements for consumers, 2018, <https://www.bportugal.pt/en/comunicado/banco-de-portugal-applies-macroprudential-measures-new-credit-agreements-consumers> [dostęp: 15.03.2019]. 


\begin{tabular}{|l|c|c|c|c|c|c|c|c|}
\hline Słowenia & - & $\checkmark$ & - & - & - & $\checkmark$ & - & - \\
\hline Szwecja & $\checkmark$ & - & - & - & $\checkmark$ & - & - & - \\
\hline Węgry & $\checkmark$ & - & - & - & $\checkmark$ & - & - & - \\
\hline $\begin{array}{l}\text { Wielka } \\
\text { Brytania }\end{array}$ & - & - & - & - & $\checkmark$ & - & - & - \\
\hline
\end{tabular}

${ }^{a}$ rekomendacja nadzorcza; ${ }^{b}$ wprowadzenie środka; ${ }^{c}$ brak wprowadzenia środka

Źródło: opracowanie własne na podstawie ESRB (2019): 96-101; 103-104, oraz < https://www.esrb.europa.eu/national_policy/other/html/index.en.html> [dostęp: 10.03.2019].

Zdecydowana większość krajów zdecydowała, że odpowiednio określone limity mają być uwzględniane przez wszystkich kredytodawców. Luksemburg jest $\mathrm{w}$ tym zakresie wyjątkiem, ponieważ wymogi LTV obowiąujące $\mathrm{w}$ tym kraju dotyczą jedynie banków stosujących standardową metodę szacowania ryzyka kredytowego ${ }^{16}$.

\section{OGRANICZENIE MOŻLIWOŚCI WYKORZYSTANIA WARTOŚCI NIERUCHOMOŚCI JAKO ZABEZPIECZENIA KREDYTU}

W opinii Międzynarodowego Funduszu Walutowego ustanawianie limitu LTV jest najczęściej stosowanym instrumentem makroostrożnościowym, który nie podlega harmonizacji ${ }^{17}$. Wydaje się, że po raz pierwszy taki środek został wprowadzony w 1991 r. w Hongkongu ${ }^{18}$. Podstawowym celem ograniczeń typu LTV jest eliminowanie stanu, w którym jedynym źródłem finansowania zakupu nieruchomości jest kredyt hipoteczny. Niemożność zaciagnięcia kredytu z LTV wyższym niż 100\% zmniejsza poziom ryzyka systemowego, gdyż nawet spadek cen nieruchomości nie generuje konieczności wnoszenie dodatkowego zabezpieczenia ${ }^{19}$. Ponadto wymóg zgromadzenia wkładu własnego selekcjonuje kredytobiorców, co ogranicza późniejsze problemy w spłacie kredytu. Konsekwencją wymogów LTV jest ograniczenie dostępu do bankowego finansowania nieruchomości osób o najgorszej sytuacji społeczno-ekonomicznej, co przy niskim rozwoju mieszkalnictwa na wynajem i słabej ochronie praw lokatorskich może pogorszyć warunki mieszkaniowe. Jednakże twórcy polityk publicznych mają do dyspozycji wiele narzędzi, które mogą poprawić pozycję tych osób dużo efektywniej niż zniesienie wymogów LTV.

16 Zob. Stanek (2017) i cytowana tam literatura.

${ }_{17}$ MFW (2013): 50. Z uwagi na pełne wdrożenie pakietu CRDIV/CRR (tj. aktów wskazanych w przyp. 9) do prawodawstwa państw należących do EOG bufory kapitałowe są jeszcze częściej stosowane, ale są one ukierunkowane na kredytodawców.

18 HKMA (2011): 165.

19 Sprzedaż nieruchomości z LTV < 100\% pozwala na uzyskanie środków na spłatę całego zobowiązania kredytowego. Oznacza to istotny spadek parametru LGD (loss given default), czyli zmniejszenie ryzyka kredytowego - Olszak, Świtała (2015): 52. 
Mimo że podstawowa idea ograniczeń typu LTV, czyli odmowa kredytowania całej wartości nieruchomości, jest relatywnie prosta ${ }^{20}$, istnieje szereg możliwości zróżnicowania zakresu ich stosowania. Spośród państw EOG stosujących wymogi LTV - Austria, Holandia, Liechtenstein, Litwa, Słowenia i Szwecja przyjęły, że maksymalna dopuszczalna wartość tego współczynnika jest taka sama dla wszystkich kredytobiorców (zob. tabela 2).

Tabela 2

Zakres stosowania wymogów LTV w odniesieniu do nieruchomości mieszkaniowych w państwach EOG (stan z czerwca 2019 r.)

\begin{tabular}{|c|c|c|}
\hline Państwo & $\begin{array}{l}\text { Maksymalna } \\
\text { wartość LTV }{ }^{a}\end{array}$ & $\begin{array}{l}\text { Zróżnicowanie zakresu } \\
\text { stosowania LTV }\end{array}$ \\
\hline Austria & $80 \%$ & brak \\
\hline Cypr & $80 \%$ & pierwsza/kolejna nieruchomość \\
\hline Czechy & $90 \%$ & $\begin{array}{l}\text { ograniczenie udziału kredytów z wysokim LTV, cel zakupu } \\
\text { nieruchomości }\end{array}$ \\
\hline Dania & $95 \%$ & ograniczenie udziału kredytów typu interest-only \\
\hline Estonia & $90 \%$ & $\begin{array}{l}\text { sposób zabezpieczenia kredytu, część kredytów może nie speł- } \\
\text { niać wymogów LTV }\end{array}$ \\
\hline Finlandia & $95 \%$ & pierwsza/kolejna zakupiona nieruchomość \\
\hline Holandia & $100 \%$ & brak \\
\hline Irlandia & $90 \%$ & pierwsza/kolejna nieruchomość, zakup mieszkań na wynajem \\
\hline Islandia & $90 \%$ & pierwsza/kolejna nieruchomość \\
\hline Liechtenstein & $80 \%$ & brak \\
\hline Litwa & $85 \%$ & brak \\
\hline Luksemburg & $80 \%$ & metoda szacowania ryzyka kredytowego \\
\hline Łotwa & $95 \%$ & sposób zabezpieczenia kredytu \\
\hline Malta & $70 \%$ & metoda szacowania ryzyka kredytowego \\
\hline Norwegia & $85 \%$ & $\begin{array}{l}\text { pierwsza/kolejna nieruchomość, położenie nieruchomości, } \\
\text { część kredytów może nie spełniać wymogów LTV }\end{array}$ \\
\hline Polska & $90 \%$ & sposób zabezpieczenia kredytu \\
\hline Portugalia & $90 \%$ & sposób wykorzystania nieruchomości \\
\hline Rumunia & $95 \%$ & $\begin{array}{l}\text { korzystanie z publicznego dofinansowania, waluta, w której } \\
\text { denominowany jest kredyt }\end{array}$ \\
\hline Słowacja & $90 \%$ & ograniczenie udziału pożyczek z wysokim LTV w portfelu \\
\hline Słowenia & $80 \%$ & brak \\
\hline Szwecja & $85 \%$ & wyższe wymogi amortyzacyjne dla pożyczek o wysokim LTV \\
\hline Węgry & $80 \%$ & waluta, w której denominowany jest kredyt \\
\hline
\end{tabular}

${ }^{a}$ W kolumnie drugiej podano maksymalną dopuszczalną wartość LTV, która może dotyczyć tylko części udzielanych kredytów.

Źródło: jak w tabeli 1.

${ }^{20}$ Mimo wszystko można wyróżnić kilka wariantów ujmowania LTV. Analizuje je Thebault (2017): 23-24. 
Osoby kupujące mieszkanie w celu wynajmu cechują się wyższą skłonnością do ryzyka niż osoby nabywające nieruchomość na swoje potrzeby mieszkalne. Ponadto gospodarstwa domowe inwestujące w kolejne mieszkania sa bardziej podatne na zmiany koniunktury na rynku nieruchomości, szczególnie wówczas gdy nie dysponują innymi rodzajami aktywów, a wręcz finansuja konsumpcję bieżąca wpływami z wynajmu. Sprawia to, że zasadne może być zróżnicowanie limitu LTV w zależności od celu zakupu nieruchomości i dopuszczenie wyższej wartości LTV dla kredytobiorców kupujących nieruchomość na swoje potrzeby mieszkaniowe.

Na wprowadzenie niższego LTV dla kredytobiorców dokonujących zakupu drugiej nieruchomości zdecydowały się Cypr, Finlandia, Irlandia, Islandia oraz Norwegia. Ostatnie z wymienionych państw dokonało dodatkowo zróżnicowania wysokości LTV pomiędzy kredytobiorcami dokonującymi zakupu drugiej nieruchomości ze względu na jej położenie. Poziom ryzyka kredytowego, na które bank się wystawia, finansując nieruchomości, jest zależny od sposobu zabezpieczenia ekspozycji. W niektórych krajach Europejskiego Obszaru Gospodarczego część udzielanych kredytów mieszkalnych jest gwarantowana przez programy i instytucje rządowe, ponadto kredyt można objaćc ubezpieczeniem komercyjnym. Na wyższą wartość LTV dla kredytów gwarantowanych przez instytucje państwowe zdecydowały się Estonia i Łotwa. W Polsce możliwe jest podwyższenie LTV z 80\% do 90\%, jeśli kredyt objęty jest dodatkowo ubezpieczeniem komercyjnym ${ }^{21}$.

Kolejnymi rozwiązaniami zwiększającymi elastyczność LTV jest zwolnienie z tego wymogu części kredytów hipotecznych udzielanych w ciągu roku lub krótszego okresu. Pamiętać jednak należy o nadrzędnym celu nadzoru makroostrożnościowego, tj. ograniczaniu ryzyka systemowego. Dlatego też z reguły dopuszcza się tylko niewielką skalę odstępstw od ogólnego wymogu LTV, tak aby wykluczyć możliwość, że większa swoboda banków zagrozi stabilności finansowej. Takie rozwiązania przyjęto w Estonii, Irlandii i Norwegii ${ }^{22}$.

Na pewną odmianę powyższego rozwiązania zdecydowały się Czechy i Słowacja. W tych państwach ogólny limit LTV jest określony na względnie wysokim poziomie. Dodatkowo ustalono także wymogi wobec struktury kredytów już spełniających generalne warunki. W Słowacji wymagany współczynnik LTV wynosi 90\%, ale jedynie w wypadku 30\% udzielanych kredytów zabezpieczonych hipotecznie może on przekroczyć 80\%. W Czechach maksymalny LTV to $90 \%$, ale jedynie w wypadku $15 \%$ udzielanych kredytów hipotecznych może przekraczać $80 \%$.

Aprecjacja franka szwajcarskiego po kryzysie finansowym dobitnie unaoczniła, że kredyty powiązane z kursami walutowymi niosą ze sobą szczególne

${ }^{21}$ Pamiętać należy, że choć polisę opłaca kredytobiorca, to beneficjentem umowy jest kredytodawca. Rozwiązanie to jest określane jako ubezpieczenie niskiego wkładu - zob. Willmann (2013): 217. Alternatywą wobec ubezpieczenia, która przewiduje rekomendacja KNF, jest zabezpieczenie w formie blokady na rachunku bankowym bądź zastaw na dłużnych papierach wartościowych NBP lub Skarbu Państwa - zob. Rekomendacja 15.7 zawarta w „Rekomendacji S dotyczącej dobrych praktyk w zakresie zarządzania ekspozycjami kredytowymi zabezpieczonymi hipotecznie”, KNF, Warszawa 2013.

${ }^{22}$ ESRB (2019): 96-97. 
ryzyko systemowe ${ }^{23}$. Na uzależnienie wymogu LTV od waluty kredytu zdecydowały się Węgry i Rumunia. Podkreślić należy, że zróżnicowanie limitów wkładu własnego w zależności od waluty kredytu ogranicza dopływ nowo udzielanych kredytów zależnych od zmian kursu walutowego, to jednak nie ma wpływu na jakość już udzielonych kredytów hipotecznych.

Na wprowadzenie środka, który jest ekonomicznie powiązany z LTV, choć wprost nie określa relacji kredytu do jego zabezpieczenia, jest wymóg ratalnego spłacania kapitału początkowego (w terminologii anglojęzycznej nazywane amortyzacją kredytu $)^{24}$. Jeśli nie nastapi gwałtowny spadek wartości nieruchomości pozwala to systematycznie obniżać LTV, a więc mitygować ryzyko systemowe.

Zaprzeczeniem amortyzowania kapitału jest oferowanie kredytów spłacanych tylko w części odsetkowej (interest-only) ${ }^{25}$. Spłata zadłużenia jest wówczas możliwa tylko dzięki zbyciu nieruchomości, która zwiększyła swoją wartość w trakcie trwania umowy kredytowej. Innym rozwiązaniem jest rolowanie kredytu, tj. refinansowanie długu nowym, być może udzielonym na lepszych dla kredytobiorcy warunkach. W efekcie rośnie jednak stopień zadłużenia gospodarstw domowych. Na wprowadzenie wymogu amortyzacji, choćby częściowej, zdecydowały się: Austria, Dania, Holandia, Liechtenstein, Norwegia, Słowacja i Szwecja. W przypadku nieruchomości komercyjnych tylko Cypr i Polska wprowadziły wymogi LTV. W pierwszym przypadku limit wynosi $70 \%$ i nie podlega różnicowaniu. W Polsce generalna granica to $75 \%$, ale jeśli część ekspozycji przekraczajacca 75\% LTV jest ubezpieczona lub dodatkowo zabezpieczona blokadą środków na rachunku bądź zastawem na kwalifikowalnych papierach wartościowych, to granica LTV wynosi $80 \%$.

\section{V. ŚRODKI NADZORCZE WPROWADZAJĄCE WYMOGI DOCHODOWE DLA KREDYTOBIORCÓW}

Na poziom ryzyka systemowego związanego z kredytami hipotecznymi wpływa nie tylko jakość zabezpieczenia ekspozycji, ale także zdolność kredytobiorców do ich regularnej spłaty. Jeśli rata kredytu stanowi zbyt dużą część dochodów kredytobiorcy to w przypadku wystapienia szokowych zmian rynkowych ${ }^{26}$ może on zaprzestać spłaty, mimo że na etapie oceny wniosku pozytywnie oceniono jego zdolność kredytowa. Generowana w efekcie strata sektora bankowego może zagrozić stabilności finansowej. Dlatego aż 17 państw należących do EOG wprowadziło środki, które racjonują zadłużenie u nabywców nieruchomo-

\footnotetext{
${ }^{23}$ Ahnert et al. (2018): 2-3; Yeşin (2013): 230-233.

${ }^{24}$ Zob. Hull (2015).

${ }^{25}$ W 2007 r. takie kredyty zdobyły kilkunastoprocentowe udziały rynkowe na Cyprze oraz w Irlandii. ECB (2009): 30.

${ }^{26}$ Do których należą: recesja gospodarcza, wzrost bezrobocia, wzrost inflacji bądź stóp procentowych.
} 
ści w relacji do ich dochodu. W praktyce najczęściej stosowane są dwa ograniczenia: wymóg DSTI ${ }^{27}$ oraz DTI. Ponadto w niektórych krajach obowiązkowe jest przeprowadzenie testów warunków skrajnych, sprawdzających, czy po szoku gospodarczym kredytobiorca wciąż będzie obsługiwać swój dług.

Stosując terminologię Zalecenia ERRS/2016/14, wymóg DSTI to wskaźnik obsługi zadłużenia do dochodu; ERRS sugeruje, by określać go jako stosunek całkowitych rocznych kosztów obsługi zadłużenia (tj. wszystkich zaciagniętych kredytów) do całkowitego rocznego dochodu do dyspozycji kredytobiorcy $\mathrm{w}$ momencie udzielenia finansowania ${ }^{28}$. Warto zaznaczyć, że wyliczajac DSTI, należy odnosić się do sumy rat odsetkowo-kapitałowych, natomiast dochód do dyspozycji stanowi sumę dochodów płacowych i pozapłacowych po umniejszeniu o podatki i składki na ubezpieczenie społeczne oraz zdrowotne.

Wymogi DSTI funkcjonują w 11 państwach EOG. Także w tym przypadku obserwuje się zróżnicowanie zakresu stosowania w zależności od charakterystyki kredytobiorców, waluty finansowania oraz przekraczania granicy DSTI przez część nowego strumienia kredytów (zob. tabela 3).

\section{Tabela 3}

Zakres stosowania wymogów DSTI w odniesieniu do nieruchomości mieszkaniowych w państwach EOG (stan na koniec czerwca 2019 r.)

\begin{tabular}{|l|c|l|}
\hline \multicolumn{1}{|c|}{ Państwo } & $\begin{array}{c}\text { Maksymalna } \\
\text { wartość DSTI }\end{array}$ & \multicolumn{1}{|c|}{$\begin{array}{c}\text { Zróżnicowanie zakresu } \\
\text { stosowania DSTI }\end{array}$} \\
\hline Austria & $40,0 \%$ & brak \\
\hline Cypr & $80,0 \%$ & waluta, w której denominowany jest kredyt \\
\hline Czechy & $45,0 \%$ & część kredytów może nie spełniać wymogów DSTI \\
\hline Estonia & $50,0 \%$ & część kredytów może nie spełniać wymogów DSTI \\
\hline Holandia ${ }^{a}$ & $29,5 \%$ & dochód kredytobiorcy, wysokość oprocentowania kredytu \\
\hline Litwa & $60,0 \%$ & $\begin{array}{l}\text { testy warunków skrajnych dla stopy procentowej, część kredy- } \\
\text { tów może nie spełniać wymogów DSTI }\end{array}$ \\
\hline Polska ${ }^{a}$ & $50,0 \%$ & dochód kredytobiorcy \\
\hline Portugalia & $60,0 \%$ & część kredytów może nie spełniać wymogów DSTI \\
\hline Rumunia & $40,0 \%$ & $\begin{array}{l}\text { waluta, w której denominowany jest kredyt, ogólne zadłużenie } \\
\text { kredytobiorcy, przeznaczenie nieruchomości, częśc kredytów } \\
\text { może nie spełniać wymogów DSTI }\end{array}$ \\
\hline
\end{tabular}

27 Ponownie światowe pierwszeństwo w ustanowieniu tego rodzaju instrumentu należy przyznać nadzorowi z Hongkongu, który wymaga od banków przestrzegania limitów w tym względzie już od 1997 r. - zob. HKMA (1997): 139.

${ }^{28}$ ERRS zakłada, że w mianowniku tego wskaźnika uwzględnia się także nagrody okresowe (np. premie kwartalne lub roczne) oraz pozapłacowe źródła dochodu. Praktyka bankowa państw europejskich nie idzie w tym kierunku, tzn. te składniki sa pomijane, gdyż w ogromnej mierze raty kredytowe są płatne co miesiąc. Z tego względu DSTI oblicza się jako relację miesięcznych kosztów obsługi zadłużenia do miesięcznego dochodu do dyspozycji z tytułu pracy - przykładowo EEsti Pank (2014): 9 LB (2017): 3. W ujęciu średniorocznym oba podejścia mogą być zbieżne, ale jednak nie są tożsame. 
cd. tab. 3

\begin{tabular}{|l|c|l|}
\hline \multicolumn{1}{|c|}{ Państwo } & $\begin{array}{c}\text { Maksymalna } \\
\text { wartość DSTI }^{a}\end{array}$ & \multicolumn{1}{c|}{$\begin{array}{c}\text { Zróżnicowanie zakresu } \\
\text { stosowania DSTI }\end{array}$} \\
\hline Słowacja & $100,0 \%$ & testy warunków skrajnych dla stopy procentowej, wskaźnik DTI \\
\hline Słowenia & $67,0 \%$ & dochód kredytobiorcy \\
\hline Węgry & $60,0 \%$ & $\begin{array}{l}\text { waluta, w której denominowany jest kredyt; sposób ustalania } \\
\text { oprocentowania }\end{array}$ \\
\hline
\end{tabular}

${ }^{a}$ W kolumnie drugiej podano maksymalną dopuszczalną wartość DSTI, która może dotyczyć tylko części udzielanych kredytów.

${ }^{b}$ Sugerowany limit, który ma tylko wzmagać uwagę kredytodawcy przy ocenie zdolności kredytowej.

Źródło: jak w tabeli 1.

Limit DSTI może być zróżnicowany w zależności od wysokości dochodów kredytobiorcy. Biorac pod uwagę względnie niski udział kosztów utrzymania w miesięcznym budżecie osoby lepiej sytuowanej, z reguły będzie ona zaliczana do kredytobiorców z relatywnie niskim wskaźnikiem $\mathrm{PD}^{29}$. Takiej oceny nie zmienią nawet nominalnie większe kwoty obsługi zadłużenia, które rzutują na wzrost DSTI. Na wprowadzenie odmiennych progów DSTI w powiązaniu z zamożnością nabywcy nieruchomości mieszkaniowej zdecydowały się Holandia, Polska ${ }^{30}$, Rumunia i Słowenia.

Wspominane już ryzyko dotyczące udzielania kredytów powiązanych z kursem walutowym sprawia, że podobnie jak w przypadku LTV zasadne jest zróżnicowanie DSTI w zależności od waluty kredytu. Na zastosowanie takiego rozwiązania zdecydowały się Rumunia oraz Węgry. W pierwszym z tych państw maksymalna relacja kosztów obsługi kredytu hipotecznego (wraz z innymi kredytami) nominowanego w narodowej walucie (lei) wynosi $40 \%$ dochodu rozporządzalnego oraz $20 \%$ dla tzw. kredytów walutowych. Na Węgrzech limit dla obsługi kredytów związanych z kursem euro wynosi $30 \%$, dla innych walut tylko $10 \%$, a dla finansowania w forintach granica jest nawet $60 \%$. Zakres stosowania wymogów DSTI został częściowo ograniczony w Czechach, Estonii, na Litwie oraz w Portugalii. Dopuszczalne odstępstwa od ogólnych reguł mają dotyczyć relatywnie małych frakcji nowego strumienia finansowania. Przykładowo w Czechach 5\% udzielonych kredytów może przypaść na nabywców nieruchomości z wyższym DSTI, w Estonii podobny odsetek może już sięgać 15\%.

Uzasadnieniem takich regulacji (speed limit approach) jest uwzględnienie fazy rozwoju zawodowego kredytobiorcy. Dosyć powszechne jest zwiększenie popytu na mieszkania, współfinansowane bankowo, przez relatywnie młodych nabywców, którzy mając szanse na wyższe zarobki w przyszłości, charakteryzują się wysokim DSTI i nadal niskim PD w dacie zaciągania zobowiązania.

${ }^{29} \mathrm{PD}$ (probability of deafult) to prawdopodobieństwo niewykonania zobowiązań kredytowych przez klienta. Klasyfikację klientów z punktu widzenia PD wyjaśnia m.in. Kulczycki (2015): 19.

${ }_{30}$ Warto zauważyć, że Komisja Nadzoru Finansowego w Rekomendacji S z 2013 r. używa akronimu DtI (pkt 20 „Słowniczka stosowanych pojęć”), ale ekonomiczny sens wymogu jest tożsamy z parametrem DSTI. 
Zatem większa elastyczność decyzyjna jest pożądana, o ile powiąże się ją z dokładniejszą oceną zdolności kredytowej ${ }^{31}$.

Informacje zawarte w tabeli 3 pokazuja, że stosowanie DSTI dalekie jest od harmonizacji znanej z innych obszarów regulacji bankowych. Nie sposób odnaleźć wzorca opisującego większość uwzględnionych krajów. Nawet maksymalny limit DSTI wykazuje rozpiętość od 29,5\% do $100 \%$. Wskazuje to na brak międzynarodowego standardu, choć w literaturze przedmiotu odnaleźć można sugestie, że przekroczenie $40 \%$ powinno być traktowane jako sygnał ostrzegawczy ${ }^{32}$.

Limit DSTI dotyczący nieruchomości komercyjnych ustanowiły tylko Cypr i Dania. W pierwszym przypadku pułap wynosi 80\%, a definicja dochodu wskazuje, że analizowany instrument ogranicza popyt na lokale nabywane przez gospodarstwa domowe na wynajem. W Danii granica to $100 \%$, ale mianownikiem jest zysk przed opodatkowaniem, co wskazuje, że adresatami DSTI są osoby prawne.

Wymogi dotyczące DSTI bazują na relacji raty odsetkowo-kapitałowej do dochodu kredytobiorcy. Licznik tej miary jest wrażliwy na wysokość stopy procentowej z chwili udzielenia kredytu oraz długość umowy. Niska stopa procentowa i długi okres kredytowania oznaczają niska ratę i w efekcie znalezienie się pod progiem DSTI. Jednakże skok oprocentowania może zmienić relacje ustalone na początku umowy kredytowej. Z tego względu ERRS postuluje korzystanie także ze wskaźnika DTI, który określa wartość całkowitego zadłużenia do rocznego dochodu do dyspozycji. Zatem DTI jest niewrażliwe na zmiany stóp procentowych oraz termin spłaty, gdyz licznik tej miary to kwota z dnia podpisania umowy kredytowej.

Wykorzystanie DTI jako element oceny wiarygodności kredytowej oznacza ustalenie dopuszczalnego zadłużenia jako krotności rocznego dochodu nabywcy nieruchomości. Takie wymogi są stosowane rzadziej niż DSTI, ponieważ stanowią komplementarny środek polityki nadzorczej (zob. tabela 4).

Tabela 4

Zakres stosowania wymogów DTI dla nieruchomości mieszkalnych w państwach EOG (stan na koniec czerwca 2019 r.)

\begin{tabular}{|l|c|l|}
\hline \multicolumn{1}{|c|}{ Państwo } & $\begin{array}{c}\text { Maksymalna } \\
\text { wartość DTI }\end{array}$ & Zróżnicowanie zakresu stosowania DTI \\
\hline Czechy & 9,0 & część kredytów może nie spełniać wymogów DTI \\
\hline Dania & nieokreślona & $\begin{array}{l}\text { położenie nieruchomości, test warunków skrajnych mająt- } \\
\text { ku netto dla DTI }>\text { 4, niemoźnośc uzyskania kredytu ze } \\
\text { zmienną stopa procentową dla DTI }>4 \text { i LTV }>60 \%\end{array}$ \\
\hline Irlandia & nieokreślona & ograniczenie udziału kredytów z DTI $>3,5$ \\
\hline
\end{tabular}

31 Jednocześnie bank musi dysponować odpowiednim buforem kapitałowym na pokrycie ewentualnych błędów wynikających z odstapienia od wytycznych nadzoru - zob. Spencer (2013): 4.

32 May, Tudela (2005): 36-37; Albacete, Lindner (2013): 65-66. 
cd. tab. 4

\begin{tabular}{|c|c|c|}
\hline Państwo & $\begin{array}{l}\text { Maksymalna } \\
\text { wartość DTI }^{a}\end{array}$ & Zróżnicowanie zakresu stosowania DTI \\
\hline Norwegia & 5,0 & część kredytów może nie spełniać wymogów DTI \\
\hline Słowacja & 8,0 & część kredytów może nie spełniać wymogów DTI \\
\hline Szwecja & nieokreślona & ograniczenie udziału kredytów z DTI > 4,5 \\
\hline Wielka Brytania & nieokreślona & ograniczenie udziału kredytów z DTI > 4,5 \\
\hline
\end{tabular}

${ }^{a} \mathrm{~W}$ kolumnie drugiej podana jest maksymalna dopuszczalna wartość DTI, która może dotyczyć tylko części udzielanych kredytów.

Źródło: jak w tabeli 1.

Wymóg dochodowy oparty na DTI podlega w praktyce nadzorczej modyfikacjom. Przykładowo w Danii maksymalna dopuszczalna wartość analizowanego współczynnika uzależniona jest od tego, czy nieruchomość, na której zakup udzielono kredytu hipotecznego, znajduje się w obszarze, w którym ostatnio nastapił szybki wzrost cen nieruchomości. Jeśli wartość DTI przekracza cztery, to udzielenie kredytu hipotecznego jest możliwe tylko wtedy, gdy po spadku cen nieruchomości o 10\% gospodarstwo domowe wciąż posiadać będzie dodatni majątek netto, czyli wartość jego aktywów przekraczać będzie wartość zobowiązań. Jeśli DTI przekracza pięć, to dodatnia wartość majątku netto musi utrzymać się w nawet przy spadku wartości nieruchomości o $25 \%$. Zatem uzyskanie de facto wyłączenia spod wymogu DTI wydaje się stosunkowo łatwe dla duńskich gospodarstw domowych, dla których nieruchomość nie jest najważniejszym składnikiem majątku. Ogół gospodarstw domowych w Danii dysponuje na tyle znaczącymi aktywami finansowymi ${ }^{33}$, że ich majątku netto nie należy traktować jako wysoce elastycznego względem cen nieruchomości.

W pozostałych państwach wskazanych w tabeli 4 wymóg DTI stosowany jest jedynie do części udzielanych kredytów zabezpieczonych hipotecznie. W Czechach 5\% udzielonych kredytów mieszkaniowych może charakteryzować się DTI przekraczajacym 9 . W Irlandii 80\% kredytów na drugie lub kolejne nieruchomości mieszkalne musi być związane z DTI niższym niż 3,5. Dla nabywców pierwszych mieszkań odpowiedni udział wynosi $90 \%$. W Norwegii $10 \%$ udzielanych kredytów zabezpieczonych hipotecznie może cechować się wyższą wartością DTI niż 5. W Wielkiej Brytanii dopuszczalna wartość DTI wynosząca 4,5 może być przekroczona przez maksymalnie 15\% udzielanych kredytów hipotecznych. Z kolei w Szwecji udzielenie kredytu nabywcy, który charakteryzuje się DTI powyżej 4,5 , wymusza przyspieszoną amortyzację kapitału początkowego.

\section{PODSUMOWANIE}

Globalny kryzys gospodarczy udowodnił siłę powiązań pomiędzy sytuacją na rynku nieruchomości oraz stabilnością sektora finansowego. Na podstawie zdobytych w jego trakcie doświadczeń szereg państw zdecydowało się na wpro-

${ }^{33}$ Zob. Isaksen et al. (2011): 42-43. 
wadzenie regulacji zwiększających odporność sektora bankowego oraz ograniczających nadmierne zadłużanie się związane z kredytami hipotecznymi.

Przedstawiona w niniejszym artykule analiza środków oddziałujacych na kredytobiorców hipotecznych wskazuje, że przymiot braku ich harmonizacji ma nie tylko wymiar formalny, lecz także przedmiotowy. Aspekt formalny wynika z tego, że wprowadzanie poszczególnych instrumentów nie odbywa się na podstawie aktów prawnych Unii Europejskiej. Natomiast wymiar przedmiotowy koncertuje się na odmienności konstrukcyjnej zastosowanych środków, zwłaszcza zróżnicowaniu wykreowanych wymogów oraz skali możliwych włączeń ${ }^{34}$.

Zaprezentowane porównania wykazały, że największą popularnością w państwach EOG cieszą się wymogi typu LTV (ang. loan-to-value), aczkolwiek nie można pominąć zakresu stosowania ograniczeń związanych z DSTI (ang. debt-service-to-income) i DTI (ang. debt-to-income). Warto zauważyć, że mimo na pozór prostej struktury wspomnianych instrumentów istnieją znaczne możliwości ich dostosowania do priorytetów twórców polityk publicznych. Tym samym wymienione środki nadzoru bankowego, zwłaszcza sensu largo (makroostrożnościowe), pozwalają na elastyczne regulowanie popytu na kredyty hipoteczne w sposób, który uwzględnia specyfikę krajowego rynku nieruchomości.

\section{Michat Kruszka}

Akademia Finansów i Bankowości Vistula w Warszawie

m.kruszka@vistula.edu.pl

https://orcid.org/0000-0002-9138-7225

Marcin Wroński

Szkoła Gtówna Handlowa w Warszawie marcin.wronski@doktorant.sgh.waw.pl

https://orcid.org/0000-0002-3146-601X

Ahnert, T., Forbes, M., Friedrich C., Reinhardt, D. (2018). Macroprudential FX regulations: shifting the snowbanks of FX vulnerability? Bank of Canada Staff Working Paper 2018-55.

Akinci, O., lmstead-Rumsey, J. (2015). How effective are macroprudential policies? An empirical Investigation. International Finance Discussion Papers Board of Governors of the Federal Reserve System No. 1136.

Albacete, N., Lindner, P. (2013). Household vulnerability in Austria - a microeconomic analysis based on the household finance and consumption survey. Financial Stability Report 25, OeNB: 57-73.

${ }^{34} \mathrm{~W}$ związku z powyższym wątpliwe jest ocenianie skuteczności wprowadzanych ograniczeń na podstawie analiz statystycznych, które pomijają wątek heterogeniczności instrumentów oddziałujących na kredytobiorców - jak np. w pracy Akinc, Olmstead-Rumsey (2015). W opinii autorów zasadne jest wyłącznie prowadzenie studiów przypadków, koncentrujące się na danym kraju, tj. z zachowaniem homogeniczności stosowanych wymogów. Tego rodzaju badania prezentują m.in. Albacete, Fessler, Lindner (2018): 67-83, oraz MFW (2018): 9-21. Wskazano w nich na skuteczność analizowanych tu środków, ale wyłącznie jako składowych tzw. policy-mix, tj. uzupełnionych instrumentami oddziałującymi na kredytodawców (wymogi kapitałowe oraz narzędzia polityki pieniężnej). 
Albacete, N., Fessler, P., Lindner, P. (2018). One policy to rule them all? On the effectiveness of LTV, DTI and DSTI ratio limits as macroprudential policy tools. Financial Stability Report 35, OeNB: 67-83.

BdP (2018). Banco de Portugal applies macroprudential measures to new credit agreements for consumers. <https://www.bportugal.pt/en/comunicado/banco-de-portugal-applies-macroprudential-measures-new-credit-agreements-consumers> [dostęp: 15.03.2019].

BaFin (2017). Residential mortgage loans: BaFin gains new macro-prudential powers. <https:// www.bafin.de/SharedDocs/Veroeffentlichungen/EN/Fachartikel/2017/fa_bj_1706_wohnimmobilienkredite_en.html> [dostęp: 15.03.2019].

Brummer, C. (2015). Soft Law and the Global Financial System. Law Making in the 21st Century. New York.

Dietsch, M., Welter-Nicol, C. (2014). Do LTV and DSTI caps make banks more resilient? Débats économiques et financiers 13.

ESRB (2018). A Review of Macroprudential Policy in the EU in 2017. Frankfurt am Main.

Fedorowicz, M. (2013). Nadzór nad rynkiem finansowym Unii Europejskiej. Warszawa.

Freixas, X., Laeven, L., Peydró, J.-L. (2015). Systemic Risk, Crises, and Macroprudential Regulation. Cambridge.

Grossman, E., Leblond, P. (2011). European financial integration: finally the great leap forward? Journal of Common Market Studies 49(2): 413-435.

Hainz, C., Hristov, N. (2017). Credit crunch indicator: perceptions of the willingness of banks to lend and firms' experience in the credit market, 18, 2017, CESifo Forum 2: 66-69.

HKMA (1997). Supervisor's memo. HKMA Quarterly Bulletin 12: 138-140.

HKMA (2011). Loan-to-value ratio as a macroprudential tool - Hong Kong SAR's experience and cross-country evidence. BIS Papers 57: 163-178.

Hull, I. (2015). Amortization requirements and household indebtedness: an application to Swedish-style mortgages. Sveriges Riksbank Working Paper Series No 298.

Isaksen, J., Lassenius Kramp, P., Funch Sørensen, L., Vester Sørensen, S. (2011). Household balance sheets and debt - an international country study. Monetary Review 2011(4), Danmarks Nationalbank: 39-81.

Jonung, L. (2008). Lessons from financial liberalisation in Scandinavia. Comparative Economic Studies 50(4): 564-598.

Legutko, A.J. (2017). Iceland's financial crisis in 2008. Political, Economic and Social Consequences, International Studies 20(1): 113-130.

May, O., Tudela, M. (2005). When is mortgage indebtedness a financial burden to British households? A dynamic probit approach. Bank of England Working Paper No 277.

MFW (2013). Key Aspects of Macroprudential Policy. Washington. <https://www.imf.org/external/ np/pp/eng/2013/061013b.pdf> [dostęp: 15.03.2019].

MFW (2018). Macroprudential Policies and House Prices in Europe: An Overview of Recent Experiences, Regional Economic Outlook. Europe - Domestic Expansion Running into External Turbulence: 9-21.

Nieborak, T. (2010). Globalny kryzys finansowy - istota, przyczyny, konsekwencje. Ruch Prawniczy, Ekonomiczny i Socjologiczny 72(4): 95-106.

Nieborak, T. (2017). Soft lex, sed lex? O nowych formach regulacji rynku finansowego Unii Europejskiej. Przegląd Zachodni 2(363): 205-217.

Norris, M., Byrn, M. (2015). Asset price Keynesianism, regional imbalances and the Irish and Spanish housing booms and busts. UCD Geary Institute for Public Policy Discussion Paper Series, WP2015/14.

Olszak, M. (2012). Polityka ostrożnościowa w ujęciu makro: cel, instrumenty i architektura instytucjonalna. Problemy Zarządzania 10(1): 7-32.

Olszak, M., Świtała, F. (2015). Antycykliczne instrumenty polityki makroostrożnościowej wpływające na rynek nieruchomości w Unii Europejskiej. Bezpieczny Bank 4(61): 41-66.

Rosati, D.K. (2016). Nowe tendencje w polityce pieniężnej po kryzysie finansowym 2008-2012. Finanse, Rynki Finansowe, Ubezpieczenia 82(4): 461-490.

Spencer, G. (2013). Macro-prudential policy and the New Zealand housing market, Wellington. $<$ https://www.rbnz.govt.nz/-/media/ReserveBank/Files/Publications/Speeches/2013/5335449. pdf?revision=c482f710-d5b6-444e-9879-34e58f9c2dbc > [dostęp: 8.09.2019]. 
Stanek, T. (2017). Rekomendacje Komitetu Bazylejskiego w zakresie oceny ryzyka kredytowego dla metody standardowej. Studia i Prace Kolegium Zarządzania i Finansów 158: 75-93.

Szpringer, M., Szpringer, W. (2017). The European system of financial supervision - regulatory impact assessment. Journal of Banking and Financial Economics 8(2): 84-104.

Thebault, L. (2017). The "V" in LTV and why it matters, [w:] Review of Europe's Mortgage and Housing Markets. Hypostat. EMF. Brussels: 23-31.

Willmann, M. (2013). Wpływ rekomendacji nadzorczych na kształtowanie się rynku kredytów mieszkaniowych w Polsce. Nauki o Finansach - Financial Sciences 1(14): 204-225.

Wyciślak, S. (2012). Efekt zarażania w mechanizmie rozprzestrzeniania się kryzysu. Ekonomista 2: 243-252.

Yeşin, P. (2013). Foreign currency loans and systemic risk in Europe. Federal Reserve Bank of St. Louis Review 95(3): 219-236.

\section{PRUDENTIAL STANDARDS FOR THE ASSESSMENT OF A MORTGAGE BORROWER'S CREDIT RISK}

\section{Sum mary}

The recent financial crisis revealed a significant link between the stability of the banking system and real estate lending. The aim of the article is to present the supervisory measures (in the narrow and in the broader sense) employed in banking as factors that can limit the demand for real estate lending. The study covers supervisory measures implemented in the European Economic Area countries. Supervisory instruments restricting the use of real estate as collateral for loans and instruments imposing income requirements on borrowers are discussed. Particular attention has been paid to the link between the priorities of financial market regulators in a given country and the international differentiation of the supervisory measures.

Keywords: supervisory measures; banking; real estate lending 
